\title{
Kamil Kościelski \\ Stojąc przed zamkniętymi drzwiami. Franz Kafka Piotra Dumały
}

\begin{abstract}
Kościelski Kamil, "Stojąc przed zamkniętymi drzwiami. Franz Kafka” Piotra Dumały [Standing in front of a closed door. Piotr Dumała's Franz Kafka] „Przestrzenie Teorii” 24, Poznań 2015, Adam Mickiewicz University Press, pp. 275-291. ISBN 978-83-232-2982-7. ISSN 1644-6763. DOI 10.14746/pt.2015.24.15.
\end{abstract}

Directed by Piotr Dumala, Franz Kafka is a very unusual example of a biographical movie. The film is composed of carefully thought-out poetic images which, according to the director himself, reflect the "psychic landscape" of the title character. Thus scenes inspired by Kafka's life and his Diaries intertwine with episodes that refer to his literary works. Dumala shows deep understanding of the writer's characteristic way of depicting reality and the unusual perspective of narration indicates his thorough knowledge of Kafka's works. Dumala draws on this heritage and creates an emotional portrait of the writer, while at the same time providing a universal reflection on the human condition.

Wśród szerokiego grona fanów animacji nazwisko Piotra Dumały budzi w pierwszej kolejności skojarzenie z tzw. techniką płytek gipsowych, którą polski twórca odkrył zupełnie przypadkowo. Jak relacjonuje Jerzy Armata, Dumała odnalazł kiedyś w pracowni

starą deseczkę, jeszcze z czasów szkolnych, która pozostała z lekcji technologii malarstwa. To była sklejka, na której w liceum plastycznym uczył się nakładać grunt kredowo-gipsowy. Postanowił na niej namalować coś w stylu dawnych mistrzów holenderskich. A że malowali oni raczej w mrocznych tonacjach, pokrył deseczkę najpierw ciemnym gruntem, po czym rylcem zaczął zeskrobywać zarys przyszłego obrazu. To jedyny sposób, aby coś było widać, wszak tło było ciemne. I w tym momencie olśnienie: jeśli z ciemnego tła da się „odkrywać” rysunek, to również można go animować ${ }^{1}$.

Ta nowatorska technika wydrapywania i zamalowywania obrazów na płytach gipsowych okazała się bardzo czasochłonna i wymagała od polskiego twórcy iście benedyktyńskiej pracy. Dla przykładu realizacja trzydziestominutowej adaptacji Zbrodni i kary Fiodora Dostojewskiego zajęła Dumale trzy i pół roku. W tym czasie twórca przygotował około 50 tysięcy płyt gipsowych, z których każda z osobna odpowiadała pojedynczemu

1 J. Armata, 1981-1990: Przerwana dekada, [w:] Polski film animowany, pod red. M. Giżyckiego i B. Zmudzińskiego, Warszawa 2008, s. 91. 
kadrowi filmowemu ${ }^{2}$. Walory estetyczne obrazu rekompensowały jednak trud związany z zastosowaniem wspomnianej techniki animacji. Marcin Giżycki zwraca uwagę, że Dumała: „malując i przemalowując, drapiąc i ścierając jeden i ten sam obraz, [...] uzyskuje piękne, miękkie przejścia między sekwencjami i zaskakująco bogatą fakturę, przywodzącą na myśl malarskie płótno"3. W przypadku omawianego twórcy przygotowania do projektu nie sprowadzają się jednak tylko i wyłącznie do kwestii związanych ze stroną formalną filmu. Na przykładzie Franza Kafki (1991) Piotra Dumały doskonale widać, że pracę nad animacją poprzedziła wnikliwa lektura najróżniejszych utworów praskiego pisarza, a także przestudiowanie najrozmaitszych materiałów przybliżających jego sylwetkę oraz najbliższe otoczenie.

\section{"Animowany dokument"}

Pomysł na film o Kafce zrodził się w dosyć osobliwych okolicznościach. Początkowo Dumała pragnął przedstawić historię o wampirze napisaną jeszcze $\mathrm{w}$ okresie licealnym. Zgodnie z pierwotnym zamysłem cała opowieść miała być utrzymana na pograniczu dwóch uwielbianych przez twórcę konwencji - horroru i burleski. Film ten zostałby prawdopodobnie zrealizowany, gdyby reżyser „nie zapragnął jako tła użyć scenerii Pragi”, bo - jak tłumaczy Dumała -

kiedy zacząłem wertować album fotografii z początku wieku, film zaczął mi się przekształcać w wyobraźni, nabierać ciężaru. Burleska gdzieś znikła. Jesienią 1989 zacząłem próbne zdjęcia do filmu o wampirze. Ale tym razem jakoś nie wyczuwałem tematu. Coś mi przeszkadzało. Zauważyłem, że na miejscu wampira znalazł się młody człowiek, mieszkający w dziwnym mieście. [...] W pewnym momencie w pokoju mojego bohatera pojawiła się fotografia Kafki, i on sam stawał się coraz bardziej podobny do Kafki. W końcu kolega polecił mi, żebym [...] porzucił film o wampirze i zrealizował któryś z dawnych projektów: „Zbrodnię i karę" albo film o Kafce. Tego samego dnia podjąłem decyzję, że robię Kafkę ${ }^{4}$.

Nie od razu natomiast udało się twórcy rozstrzygnąć, jaki kształt powinien przyjąć nowy projekt. Według relacji samego reżysera wstępny zarys scenariusza

2 A. Tarkowski, Młoda polska animacja jeszcze raz: Dumała, Rybczyński, Wawszczyk, $<$ http://kultura20.blog.polityka.pl/2008/03/18/mloda-polska-animacja-jeszcze-raz-dumalarybczynski-wawszczyk/>, dostęp: 08.10.2015.

3 M. Giżycki, Wyobraznia zaklęta w kamieniu, „Kwartalnik Filmowy” 1997, nr 19-20, s. 124 .

4 T. Sobolewski, P. Dumała, Kafka jako bohater filmowy. Spotkanie z Piotrem Dumata, „Kino” 1992, nr 6, s. 13. 
nosił [...] cechy baśni. Miał to być film oniryczny, pełen symboli i tricków plastycznych nawiązujących do malarstwa Magritte'a, grafik Maxa Ernsta, rysunków Edwarda Goreya, wypełniony wieloma postaciami widzianymi często fragmentarycznie ${ }^{5}$.

Dumała postanowił jednak porzucić pomysł, aby „prześledzić życie Kafki jako wielowątkowy sen widziany w świetle jego" rozmaitych utworów - w tym także dzienników i listów pisarza ${ }^{6}$. Wnikliwa znajomość literackiego dorobku Kafki ze strony twórcy z całą pewnością odcisnęła piętno na ostatecznym kształcie animacji. Niemniej jednak reżyser zrezygnował z surrealistycznej konwencji, a cały projekt pod względem estetycznym zaczął zmierzać „w stronę ascetycznego dokumentu”, o czym świadczą zresztą trudy, jakie podjął Dumała, aby dotrzeć do rozmaitych materiałów archiwalnych. Ukazany na początku filmu wizerunek Kafki stanowi przecież odzwierciedlenie ostatniej fotografii, która została wykonana pisarzowi $\mathrm{w}$ Berlinie na kilka miesięcy przed jego śmiercią. Zachowane zdjęcie przedstawiające rodziców pisarza pozwala natomiast odnaleźć podobieństwo pomiędzy Hermannem Kafką a obecną w dalszej części animacji sylwetką domniemanego ojca tytułowego bohatera. Klamra kompozycyjna filmu $\mathrm{w}$ równym stopniu potęguje wrażenie, zgodnie z którym odbiorca powinien zaprezentowaną historię odczytywać w ramach biograficznej opowieści. Animacja została podzielona przez Dumałę na kilka rozdziałów, z których pierwszy ma tytuł Praga 1883, a ostatni 3 czerwca. Wspomniane fragmenty odnoszą się kolejno do roku urodzenia Kafki i do daty śmierci praskiego literata.

Opisane zabiegi pokazują, z jaką powagą Dumała potraktował swój pierwotny zamysł zrealizowania „animowanego dokumentu". Jednak decyzja o ukazaniu losów pisarza w duchu bardziej realistycznym nie była jednoznaczna $\mathrm{z}$ wyeliminowaniem $\mathrm{z}$ utworu elementów odnoszących się do poetyki snu. Reżyser, szukając klucza, który mógłby się sprawdzić w filmowej opowieści na temat pisarza, zdecydował, że najkorzystniej będzie przedstawić ją w formie „krajobrazu psychicznego Kafki i jego przemian"9. Animacja Dumały może więc sprawić niemały zawód osobom spodziewającym się tradycyjnie opowiedzianej biografii, opisującej kolejne fakty z życiorysu głównego bohatera. Jak słusznie zauważa Barbara Kosecka, rozmaite epizody filmowe układają się w swoistą „wizję marzeń,

\footnotetext{
${ }^{5}$ P. Dumała, „Kafka”, którego nie było, „Kwartalnik Filmowy” 1999, nr 26-27, s. 322.

6 Tamże, s. 322 .

7 Tamże.

8 T. Sobolewski, P. Dumała, dz. cyt., s. 13.

9 P. Dumała, M. Drygas, J. Gazda, Dochodzenie do Dostojewskiego, „Kwartalnik Filmowy" 1997, nr 19-20, s. 121.
} 
snów, wyobrażeń i lęków Kafki"10. Znajomość biografii pisarza stanowi niewątpliwie ciekawe uzupełnienie podjętej przez Dumałę próby odtworzenia na ekranie życia wewnętrznego praskiego literata. Zamierzeniem twórcy nie było jednak rekonstruowanie w filmie losów Kafki.

Pomysł przedstawienia „krajobrazu psychicznego Kafki” doprowadził w efekcie do sytuacji, w której animacja Dumały balansuje na granicy poetyki snu i konwencji realistycznej. Reżyser najprawdopodobniej zdawał sobie sprawę, że w twórczości pisarza niecodzienne elementy oraz anormalne wydarzenia zostały przedstawione w sposób bardzo zwyczajny i naturalny. Osobliwe okazują się podejmowane przez Józefa K. próby odnalezienia pomieszczenia sądowego pośród mieszkań czynszowych w starej kamienicy. Nie chcacc ujawnić prawdziwego celu swoich poszukiwań, protagonista postanawia wypytywać lokatorów o stolarza o nazwisku Lanz. Ku swojemu zaskoczeniu jedna z mieszkanek pozytywnie odpowiada na jego pytanie i zaprasza bohatera do wnętrza sąsiedniego pokoju, gdzie dochodzi do nieoczekiwanego spotkania Józefa K. z sędzią śledczym. Wszelkiego rodzaju osobliwości i anomalie obecne w świecie opisywanym przez Kafkę przyjmują niezwykle prozaiczny charakter. Dlatego też Dumała z jednej strony porzucił pierwotną koncepcję przedstawienia życia pisarza $\mathrm{w}$ formie baśni, a $\mathrm{z}$ drugiej od początku nosił się z zamiarem „wywołania ducha Kafki, wydobycia z mroku scen z jego życia, zwyczajnych, przypadkowych, ocierających się o niesamowitość [podkr. - K.K.]"11. Jak wspomina reżyser w jednym z wywiadów:

Chodziło o to, żeby za bardzo nie iść w kierunku fantastyki. Kafka jest przecież piekielnie realistyczny, bardziej realistyczny niż samo życie. I tak właśnie powinno się go pokazywać, kompletnie banalnie, nieatrakcyjnie [...]12.

Dumała pojął więc pewną „formułę" realizmu charakterystycznego dla twórczości pisarza.

\section{„Przyodziane ciało"}

Łukasz Musiał, idąc za przykładem Sokela, przywołuje utwór Przygotowania do ślubu na wsi, pragnąc zobrazować pewien szczególny dla Kafki sposób prowadzenia narracji. W opowiadaniu tym „Eduardowi Rabanowi, któremu myśl o związanych z podróżą niedogodnościach jest nadzwyczaj niemiła, przychodzi do głowy pomysł”, aby pozostać we włas-

10 B. Kosecka, „Franz Kafka” Piotra Dumaty - realizm animacji, „Kwartalnik Filmowy" 1997 , nr 19-20, s. 133.

11 P. Dumała, dz. cyt., s. 322-323.

12 T. Sobolewski, P. Dumała, dz. cyt., s. 13. 
nym łóżku, a na wieś „zamiast siebie wysłać [...] swoje... «przyodziane ciało»"13. W efekcie utwór Kafki sugeruje możliwość przyjęcia przez protagonistę dość osobliwego stanowiska. Z jednej strony wydarzenia opowiadane są z perspektywy głównego bohatera, lecz z drugiej - postać ta potrafi przyjąc wobec siebie zewnętrzny punkt widzenia. Analogiczna optyka powraca też w różnych zapiskach Kafki, czego ciekawym przykładem jest fragment listu do Maksa Broda: „To próżność i poszukiwanie przyjemności [...]. To, czego niekiedy życzy sobie człowiek naiwny: «Chciałbym umrzeć i zobaczyć, jak mnie opłakują» [...]"14. Zdaniem Musiała Dociekania psa, Sprawozdanie dla akademii, Śpiewaczka Józefina, czyli naród myszy albo też Jama odzwierciedlają podobną strategię autorską. Za sprawą pierwszego z wymienionych utworów Musiał dochodzi do wniosku, że Kafka

czyniąc narratorem psa obdarzonego ludzkim głosem i wrażliwością, [...] stosuje, być może w stopniu najradykalniejszym z dotychczasowych, metodę nagłej zmiany perspektyw. [...] Kafka wysyła tu, bardziej niż kiedykolwiek, swoje „przyodziane ciało"; przyodziane w zwierzę, choć może należałoby powiedzieć: w nieczłowieka i nie-zwierzę $e^{15}$.

Metoda Kafki opiera się zatem na pewnym paradoksie. Zwierzęce postacie $\mathrm{u}$ niego $\mathrm{w}$ swoich rozważaniach i wrażliwości wydają się bliskie człowiekowi, co pozwala na wywołanie emocjonalnej więzi pomiędzy czytelnikiem a protagonistą. Jednak wybór małpy, psa czy myszy na bohatera historii buduje u odbiorcy poczucie dystansu. Analogiczna sytuacja ma miejsce w opowiadaniu Przygotowania do ślubu na wsi. Kafka prezentuje wpierw wydarzenia z punktu widzenia protagonisty, co sprzyja utożsamianiu się czytelnika $\mathrm{z}$ bohaterem. Ten proces identyfikacji zostaje w pewnym stopniu zakłócony za sprawą wyobrażenia sobie przez postać literacką sytuacji, w której opuszcza ona swoje własne ciało i przyjmuje wobec siebie zewnętrzną perspektywę. Protagonista - a wraz z nim również czytelnik - nabiera dystansu do kolejnych opisywanych wydarzeń. Strategia autorska Kafki zakłada zatem uzyskanie dwóch przeciwstawnych względem siebie punktów widzenia, które sprawiają wrażenie jednoczesnej bliskości i dystansu wobec bohatera i opowiadanej historii.

Dumała doskonale rozpoznaje intencje praskiego pisarza i w równie ambiwalentny sposób prezentuje filmowe wydarzenia. W pierwszym uję-

${ }^{13}$ Ł. Musiał, Kafka. W poszukiwaniu utraconej rzeczywistości, Wrocław 2011, s. 120-121 .

${ }^{14}$ F. Kafka, Listy do rodziny, przyjaciót, wydawców, wybrał, przeł. i komentarzem opatrzył R. Urbański, Warszawa 2012, s. 423.

15 Ł. Musiał, dz. cyt. s. 277-278. 
ciu pojawia się zbliżenie na oczy Kafki i obraz ten jest jeszcze niejednokrotnie eksponowany w animacji. Równie często ukazuje się świat oglądany z punktu widzenia tytułowej postaci. Dumała wyraźnie sygnalizuje więc odbiorcy, z czyjej perspektywy opowiadana będzie cała historia i że filmowa rzeczywistość zostanie przefiltrowana przez wrażliwość głównego bohatera ${ }^{16}$. Reżyser wprowadza jednak do animacji ujęcia, które sprawiają wrażenie, jakby Kafka podglądał samego siebie. Parokrotnie filmowe epizody ukazywane są przez dziurkę od klucza. Nietypowa perspektywa stwarza poczucie, że tytułowy bohater $\mathrm{z}$ jednej strony jest uczestnikiem poszczególnych wydarzeń, a z drugiej strony osobą spoglądającą na swój los zupełnie z zewnątrz. „To miał być Kafka - oczami Kafki" - jak tłumaczy w jednym z wywiadów Dumała. Przyjęta przez reżysera narracja jest więc bliska metodzie opowiadania, jaką posługuje się też praski pisarz.

Dumała - czego dowodzi jeden z wywiadów - był też w pełni świadomy, że Kafka

miał dziwną łatwość wczuwania się w zwierzęta. W listach porównywał się do robaka, który nie może wdrapać się na ścianę, do psa, do kreta. Zwierzęta pojawiają się w opowiadaniach, pisanych z ich punktu widzenia ${ }^{17}$.

Dlatego też w filmie Dumały niejednokrotnie powraca wątek przemiany głównego bohatera w różnego rodzaju zwierzęta. $\mathrm{Z}$ uwagi na dotychczasowe rozważania interesująca okazuje się opinia sformułowana przez Tadeusza Sobolewskiego. Jak zauważa krytyk w rozmowie z Dumałą „obecność zwierząt w filmie dlatego wydaje się tak ważna, że pozwala oddać spojrzenie Kafki na samego siebie. Kafka - pyta Sobolewski - jest przecież kretem jakby we własnych oczach, prawda?"18. Twórca odpowiada, że pisarz „tak to opisywał w liście do Mileny [...] i w opowiadaniu «Schron»"19.

W przypadku animacji Dumały nie chodzi zatem o powierzchowną znajomość opowiadań i dzienników Kafki ani też o bezrefleksyjne adaptowanie motywów charakterystycznych dla prozy praskiego pisarza ze strony reżysera. Z powyższego wywodu wynika przecież, że twórca wykazuje się głębokim zrozumieniem dorobku praskiego pisarza już na poziomie samej narracji. Przyjęta przez Dumałę perspektywa świetnie koresponduje $\mathrm{z}$ wymową filmu, dlatego też wątek ten jest kluczowy, biorąc pod uwagę dalsze rozważania.

16 B. Kosecka, dz. cyt., s. 131.

${ }_{17}$ T. Sobolewski, P. Dumała, dz. cyt., s. 13-14.

18 Tamże, s. 14.

19 Tamże. Rzeczywiście w jednym z listów do Mileny Kafka opisywał się jako kret. Zob. F. Kafka, Listy do Mileny, przeł. F. Konopka, Kraków 1993, s. 145-146. 


\section{Drzwi}

Rozmaici autorzy podkreślali wagę, jaką w twórczości Kafki odgrywa motyw drzwi. Za koronny argument postawionej tezy uznawano jeden z najbardziej znanych fragmentów powieści Proces - legendę Przed prawem. Vladimir Nabokov w Wyktadach o literaturze poświęca jeden rozdział omówieniu opowiadania Przemiana i jego zdaniem wiele fragmentów utworu kieruje uwagę czytelnika na wątek związany z liczbą trzy oraz motywem drzwi. Spostrzeżenie Nabokova okazuje się niezwykle ciekawe ze względu na treść listu, który Kafka napisał do wydawcy, pragnąc przekazać swoje sugestię co do ewentualnego projektu okładki wspomnianego opowiadania. Pisarz kategorycznie sprzeciwiał się, aby oprawa książki w jakimkolwiek stopniu odnosiła się do tytułowej metamorfozy Gregora Samsy w ogromnego insekta. W liście do Kurta Wolffa Kafka podkreśla, że „owada nie można rysować” i „nie można go nawet pokazywać z daleka" 20 . Pisarz proponuje w zamian dwie inne sceny, które w jego odczuciu byłyby adekwatnymi ilustracjami dla opowiadania Przemiana: „rodzice i prokurent przed zamkniętymi drzwiami albo jeszcze lepiej rodzice i siostra w oświetlonym pokoju, podczas gdy drzwi do całkiem ciemnego pokoju obok są otwarte"21. Równie interesująca jest subtelna gra słów, jaką dostrzec można w przypadku nazwy ostatniej powieści Kafki. Das Schloß - czyli tytułowy Zamek - oznacza oczywiście siedzibę najwyższych władz, z którymi bohater literacki bezskutecznie próbuje nawiązać jakikolwiek kontakt. Co ciekawe, wyrazem Das Schlo $\beta$ w języku niemieckim można posłużyć się również w przypadku, kiedy mowa jest o zamku od drzwi 22 .

W animacji Piotra Dumały wspomniany motyw okazuje się równie mocno eksponowany. W jednej ze scen główny bohater stoi przez dłuższą chwilę przed zamkniętymi drzwiami. W momencie ich otwarcia następuje zaciemnienie ekranu i wyciszenie ścieżki dźwiękowej. W kolejnej scenie Dumała ukazuje świat widziany oczami głównego bohatera. Z mroku wyłania się ujęcie, w którym widać otwierające się drzwi. Rodzi się pytanie: dlaczego Dumała nie zachowuje ciągłości między dwoma przytoczonymi fragmentami? Czemu wprowadza krótką „pauzę” w scenach przynależących do tego samego filmowego epizodu, w których dochodzi w dodatku do identycznego i wydawałoby się trywialnego wydarzenia - otwarcia drzwi? Zabiegi inscenizacyjne, jakimi posłużył się Dumała, pozwalają przypuszczać, że między tymi dwoma ujęciami dochodzi do

\footnotetext{
${ }^{20}$ F. Kafka, Listy do rodziny..., s. 129.

21 Tamże, s. 129.

22 Zob. W.H. Sokel, Franz Kafka, New York, London 1966, s. 36, 42-43.
} 
jakiejś istotnej przemiany. Chcąc zrozumieć rangę opisanego wydarzenia, należałoby $\mathrm{z}$ większą uwagę spojrzeć na kolejną scenę filmu.

Kafka, wchodząc do pokoju, zauważa pewną kobietę, która obnaża przed nim własną pierś, a swoim głosem i słowami stara się uwieść głównego bohatera. Między filmowymi postaciami dochodzi w efekcie do miłosnego zbliżenia. Powiązanie ze sobą późniejszych i wcześniejszych scen daje podstawy, aby w sposób symboliczny odczytywać wątek przejścia bohatera przez drzwi do sąsiedniego pomieszczenia. Z tej perspektywy ukazany akt miłosny stanowiłby inicjację seksualną filmowego Kafki swoiste przekroczenie progu dojrzałości z jego strony. Wniosek ten znajduje zresztą potwierdzenie w wypowiedziach Dumały. Reżyser wspólnie z kompozytorem Januszem Hajdunem oglądał kolejne sekwencje filmu, które określał w zwięzły sposób, aby zobrazować współpracownikowi, jakiego rodzaju idee odzwierciedlają poszczególne epizody filmowe. „Na przykład - jak puentuje Dumała - scenę w pokoju podczas deszczu, gdy Franz leży w łóżku, nazwałem «Dojrzewanie»"23.

Warto zauważyć, że w filmie Dumały wejście w dorosłość nie sprowadza się do inicjacji seksualnej samej w sobie. Chodzi również o konsekwencje, jakie niesie ze sobą tego typu doświadczenie, umożliwiające bohaterowi odkrycie własnej fizyczności i seksualności. Miłosne zbliżenie prowokuje sytuację, w której Kafka przygląda się z uwagą swemu nagiemu ciału. Leżący na łóżku bohater nagle zamienia się w ogromnego insekta, co podkreśla, jaką niechęć i obrzydzenie budzi w nim kontemplacja własnej fizjonomii. Kafka bardzo negatywnie odnosił się do kwestii związanych z ludzką seksualnością, o czym dobitnie świadczy zapis w jednym z listów do Mileny Jesenskiej:

Ciało moje, częstokroć całymi latami spokojne, bywało potem znów aż nie do wytrzymania szarpane przez tę tęsknotę za jakąś całkiem ściśle określoną obrzydliwością, za czymś z lekka odrażającym, przykrym, plugawym. Nawet w najlepszej z nadarzających się przygód było coś z tego, jakiś zły zapaszek, trochę siarki, trochę piekła ${ }^{24}$.

W wypowiedzi literata zwraca uwage jednoczesna awersja, jaką odczuwa on względem swych pierwotnych odruchów, lecz też nieumiejętność skutecznego przeciwstawienia się własnym instynktom. Zarówno Kafkę, jak i Dumałę niewątpliwie interesował koncept pozwalający spoj-

${ }^{23}$ T. Sobolewski, P. Dumała, dz. cyt., s. 13. Zob. też P. Dumała, M. Drygas, J. Gazda, dz. cyt., s. 121.

${ }^{24}$ F. Kafka, Listy do Mileny..., s. 159. W dziennikach Kafki pojawia się też wielce wymowna uwaga: „Spółkowanie jako kara za szczęście współżycia”. F. Kafka, Dzienniki 1910-1923 (część pierwsza), przeł. J. Werter, Londyn 1993 s. 320. Zob. też E. Pawel, Franz Kafka. Koszmar rozumu, Warszawa 2003, s. 109. 
rzeć na człowieka, jak na istotę „zawieszoną” pomiędzy dwoma porządkami - światem ludzkim a zwierzęcym. W przypadku Kafki kwestia ta najwyraźniej zostaje zarysowana w utworze Sprawozdanie dla Akademii, w którym małpa relacjonuje drogę, jaką przebyła, aby w swoim zachowaniu i myśleniu upodobnić się do człowieka. Jeden z końcowych fragmentów opowiadania świetnie obrazuje wspomniane rozdarcie bohatera pomiędzy światem zwierzęcym a ludzkim:

Gdy późno w nocy powracam z bankietów, z naukowych towarzystw albo z miłych towarzyskich spotkań, oczekuje mnie mała, na pół wytresowana szympansiczka, i oddaję się razem z nią przyjemnościom naszej krwi. Za dnia nie chcę jej widzieć, ma bowiem w spojrzeniu obłęd zahukanego, tresowanego zwierzęcia; tylko ja sam go dostrzegam i nie mogę go znieśćc ${ }^{25}$.

W Sprawozdaniu dla Akademii małpa, „przeobrażając się” w człowieka, nie zatraca w pełni swej pierwotnej natury, co tłumaczy, dlaczego część opowiadań Kafki odczytywano w kontekście teorii ewolucji Karola Darwina. Tezy brytyjskiego przyrodnika prowokowały przecież na przełomie XIX i XX wieku do odmiennego spojrzenia na istotę ludzką. Teoria ewolucji zmuszała do postawienia zasadniczego pytania, czy człowiek, osiągając wyższy szczebel rozwoju, uwolnił się od swych zwierzęcych instynktów, a tym samym - czy w pełni wyzwolił się ze świata przyrody. Negatywna odpowiedź kazałaby spojrzeć w sposób dwuznaczny na naturę człowieka. Podobnie jest zresztą z protagonistą Kafki, będącym według słów Musiała „nie-człowiekiem i nie-zwierzęciem”26. Bohaterowie praskiego pisarza sprawiają przecież wrażenie istot na wyższym szczeblu rozwoju, które zostały uwięzione w ciele zwierząt. Dumała, portretując Kafkę, proponuje zresztą zbliżoną perspektywę, o czym przekonuje seria metaforycznych obrazów następująca po wspomnianym miłosnym zbliżeniu. Po akcie seksualnym bohater widzi siebie wpierw jako ogromnego insekta, a następnie, stojąc w oknie, obserwuje mężczyznę, który prowadzi psa na smyczy - czyli zwierzę, w jakie na końcu filmu przemieni się główny bohater. Obraz ten w symboliczny sposób ujmuje sytuację bohatera, który nie dostrzega możliwości porzucenia swej cielesnej powłoki. Odkryta przez tytułową postać seksualność postrzegana jest w kategoriach zniewolenia. Dumała stawia pytanie: do jakiego stopnia wolny jest człowiek, skoro w swoim myśleniu i działaniu pozostaje zależny od swych zwierzęcych odruchów? Konkluzja ta w interesujący sposób koresponduje z następującą refleksją bohatera Sprawozdania dla Akademii:

${ }^{25}$ F. Kafka, Sprawozdanie dla Akademii, [w:] Wyrok, przeł. J. Kydryński, Warszawa 1993, s. 115.

${ }^{26}$ Ł. Musiał, dz. cyt., s. 278. 
Nie myślę o tym wielkim poczuciu wszechstronnej wolności. [...] Mówiąc nawiasem: tą wolnością ludzie zbyt często się oszukują. A jak wolność zalicza się do najbardziej wzniosłych uczuć, tak i odpowiadające jej złudzenie należy do najwznioślejszych ${ }^{27}$.

Zagadnienie dotyczące wolności człowieka okazuje się interesujące z uwagi na wcześniejsze spostrzeżenia odnoszące się do zastosowanej przez Dumałę narracji. Pewne ujęcia, w których widz przygląda się wydarzeniom przez dziurkę od klucza, pozwalają wyciągnąć wniosek, że identyczną perspektywę przyjmuje też tytułowy bohater. We wspomnianych fragmentach dostrzec można kształt insekta przypatrującego się wraz $\mathrm{z}$ odbiorcą poszczególnym epizodom filmowym. Występowanie tej figury wydaje się nieprzypadkowe, biorąc pod uwagę scenę, w której przedstawiona zostaje metamorfoza głównego bohatera w robaka.

Ujęcia, w których filmowe wydarzenia ukazuje się przez dziurkę od klucza, pełnią dwojaką funkcję. Po pierwsze drzwi w animacji Dumały stają się symbolem muru stojącego pomiędzy bohaterem a światem. W identyczny sposób Kafka opisuje ten motyw w swoich Dziennikach:

W pokoju dziewcząt mały Feliks spał przy szeroko otwartych drzwiach. Po drugiej stronie w moim pokoju spałem ja. Drzwi tego pokoju były przez wzgląd na mój wiek zamknięte. Poza tym otwarte drzwi oznaczały, że Feliksa chciano jeszcze przywabić do rodziny, podczas gdy ja byłem już wyłączony ${ }^{28}$.

Zamknięte drzwi w refleksji pisarza stają się w określonych okolicznościach symbolem pewnej bariery, która oddziela literata od reszty rodziny. Nie brakuje zresztą przesłanek, aby w podobnym duchu motyw ten odczytywać w przypadku opowiadania Przemiana ${ }^{29}$. Reżyserowi

${ }^{27}$ F. Kafka, Sprawozdania dla Akademii..., s. 108.

28 Tenże, Dzienniki 1910-1923 (część pierwsza), przeł. J. Werter, Londyn 1993, s. 240.

${ }^{29}$ Sposób funkcjonowania motywu drzwi w opowiadaniu Przemiana świetnie obrazuje następujący fragment utworu: „mimo swej obecnej smutnej i obrzydliwej postaci Gregor jest jednak członkiem rodziny i nie należy traktować go jak wroga, [...] obowiązek rodzinny nakazuje przemóc wstręt i mieć dla niego cierpliwość. [...] zawsze pod wieczór zostawiano otwarte drzwi od pokoju rodzinnego, drzwi, które on [Gregor - dop. K.K.] już na godzinę lub dwie godziny przedtem zwykł był z napięciem obserwować, tak że leżąc w ciemnościach własnego pokoju i z pokoju rodzinnego niewidoczny, mógł patrzeć na całą rodzinę siedzącą przy oświetlonym stole i niejako za ogólnym zezwoleniem, a więc zupełnie inaczej niż dawniej, przysłuchiwać się rozmowom" (F. Kafka, Przemiany, [w:] tegoż, Cztery opowiadania. List do ojca, przeł. J. Kydryński, Warszawa 2003, s. 68). W kontekście całej twórczości Kafki symbolika drzwi ma oczywiście niezwykle bogaty charakter. Zob. Ł. Musiał, W poszukiwaniu straconego Kafki, „Teksty Drugie” 2013, nr 6, s. 221-241; K.E. Grözinger, Kafka a Kabała. Pierwiastek żydowski w dziele i myśleniu Franza Kafki, przeł. J. Güntner, Kraków 2006. 
z całą pewnością udało się znaleźć dość osobliwy sposób, aby ukazać wyobcowanie własnego bohatera, ale wspomniane ujęcia spełniają jeszcze jedną rolę.

Dumała $\mathrm{z}$ jednej strony ukazuje świat widziany oczami Kafki, a z drugiej strony wprowadza do filmu ujęcia, w których bohater staje się biernym obserwatorem wydarzeń, w jakich, paradoksalnie, sam czynnie uczestniczy. Podobną opinię podziela Barbara Kosecka, ujmując tę kwestię w następujący sposób: „Kafka, wciągnięty w tryby egzystencji rodziny, domu, miasta, jest jednocześnie absolutnie z tego życia wyłączony"30. Tytułowa postać sprawia zatem wrażenie bezwolnej istoty podporządkowanej określonemu scenariuszowi. Świat w perspektywie Dumały przypomina teatr, w którym poszczególne jednostki odgrywają swe role, lecz czynią to w ustalonych na wstępie ramach. W tym ujęciu człowiek nie jest istotą sprawującą całkowitą kontrolę nad swym losem, ale postacią, której wybór uzależniony jest od rozmaitych czynników ${ }^{31}$. Brak wolności zostaje zresztą przez Dumałę zdefiniowany już na samym początku filmowej historii.

\section{Narodziny i śmierć}

W pierwszym ujęciu ukazują się oczy głównego bohatera. Następuje odjazd kamery i nagły rozbłysk lampy rzuca światło na jego szczupłą i bladą twarz. Dumała odtwarza na ekranie sytuację, w której doszło do wykonania ostatniej zachowanej fotografii Franza Kafka. Pisarz już od kilku lat zmagał się z gruźlicą i w pełni zdawał sobie sprawę, że jego walka z chorobą nieubłagalnie zmierza ku tragicznemu końcowi. Uporczywy kaszel, męczący głównego bohatera w pierwszej scenie filmu, jest jednym z najbardziej charakterystycznych objawów gruźlicy. Można zatem przypuszczać, że Dumała był świadomy, w jakich okolicznościach wykonane zostało ostatnie zdjęcie Kafki. Końcowe ujęcie z prologu filmu nie ukazuje oddalającej się poza ramy kadru sylwetki pisarza, lecz scenę, w której Kafka powoli podnosi się z krzesła i zupełnie niespodziewanie „znika [z ekranu - dop. K.K.] jak widmo"32. Dumała pozostawia widza na kilka sekund z niezwykle sugestywnym obrazem pustego miejsca, jakie jeszcze przed momentem zajmował tytułowy bohater.

${ }^{30}$ B. Kosecka, dz. cyt., s. 134.

31 Twórczość Kafki zestawiano zresztą z filozofią gnostycką, która świetnie koresponduje z refleksjami na temat dorobku praskiego pisarza i filmu Dumały. Ł. Musiał, W poszukiwaniu straconego...; Zob. też H. Jonas, Gnostycyzm a umysłowość klasyczna, przeł. M. Klimowicz, „Znak” 1991, nr 7, s. 11-24.

32 P. Dumała, Franz Kafka - scenariusz, „Kwartalnik Filmowy” 1999, nr 26-27, s. 324. 
Reżyser nieprzypadkowo już na samym wstępie filmu nakierowuje uwagę odbiorcy na tematykę śmierci. Prolog utworu uświadamia, że los głównego bohatera został przypieczętowany jeszcze przez rozpoczęciem się całej historii. Identyczną myślą w odniesieniu do swego filmu dzieli się zresztą sam reżyser: „Już teraz jesteś umarły - mówią mistrzowie Zen"33. W filmie niejednokrotnie daje się zauważyć wątek, w którym narodziny okazują się bezpośrednio powiązane ze śmiercią, co najwyraźniej widać w przypadku dwóch końcowych rozdziałów. Obecny w przedostatnim fragmencie obraz wschodzącego słońca i kwitnących kwiatów wskazuje, że słuszne jest wiązanie tytułu opisanego segmentu - 3 lipca $\mathrm{z}$ datą urodzin pisarza. Tym bardziej gorzko wybrzmiewa finałowa sekwencja animacji, której nazwa nawiązuje do dnia śmierci Kafki.

Dumała w wielu fragmentach filmu sugeruje widzowi, że już w początku historii kryje się zapowiedź jej końca. W jednym z pierwszych rozdziałów, zatytułowanym 1893, pojawia się dwóch mężczyzn, którzy stoją na klatce schodowej i pukają do drzwi mieszkania bohatera. Sylwetki obu mężczyzn powracają w zakończeniu filmu. Fragment ukazujący wspomniane najście przywodzi na myśl pierwszy i ostatni rozdział Procesu, któremu początkowy zarys scenariusza był „bliski [...] w swoim ostatecznym przesłaniu" 34 . Sam reżyser nakłania do poszukiwania opisanej analogii, czego przykładem może być motyw psa powracający wielokrotnie w animacji Dumały ${ }^{35}$. W ostatniej scenie główny bohater powoli zaczyna przemieniać się we wspomniane zwierzę. Przytoczona scena przypomina końcową egzekucję Józefa K. z rąk zagadkowych mężczyzn, podczas której główny bohater - według własnych słów - umiera ,jak pies”. Nietrudno zatem odgadnąć, czego metaforą jest ostatnia scena filmu. Tytułowy bohater przemienia się w psa i odbiegając od stołu, przewraca krzesło i strąca leżący przed nim talerz. Ukazanie obu tych wydarzeń w zwolnionym tempie potęguje wrażenie kruchości otaczającego świata.

Zgodnie $\mathrm{z}$ wizją Dumały świadomość śmierci rodzi się u filmowego Kafki w bardzo młodym wieku. Tytuł rozdziału, w którym dochodzi do pierwszego spotkania z tajemniczymi mężczyznami, sugeruje, że tytułowy bohater ma wtedy ukończone zaledwie dziesięć lat. Spoglądając na opisany fragment z perspektywy Procesu, należy mieć na uwadze interpretację traktującą powieść praskiego pisarza jako metaforę ludzkiego losu. Według pewnych autorów sytuacja ukazana w Kafkowskiej powieści odzwierciedla postawę człowieka rozpaczliwie buntującego się przeciwko

33 Tenże, „Kafka”, którego nie było, „Kwartalnik Filmowy” 1999, nr 26-27, s. 322.

${ }^{34}$ Tamże, s. 322. Dumała w jednym z wywiadów wprost sugerował, że sylwetki obu mężczyzn nawiązują do bohaterów Procesu.

${ }_{35}$ T. Sobolewski, P. Dumała, dz. cyt., s. 14. 
własnemu przeznaczeniu, które od samego początku nie daje nadziei na ucieczkę przed „nieuchronnym”. Dlatego nie sposób zgodzić się z opinią Barbary Koseckiej, że: „niespodziewana wizyta obcych [...] to wyzwanie, «zaproszenie do życia», pytanie postawione młodemu chłopcu”36. Niezapowiedziane najście obu mężczyzn w początkowej partii filmu nie pozostawia jakichkolwiek złudzeń, że we wstępie całej historii - niezależnie od jej przebiegu - kryje się jej tragiczny koniec...

\section{Próby wyzwolenia}

W jednym z epizodów Dumała pokazuje domowników zgromadzonych podczas posiłku przy rodzinnym stole. Smutne spojrzenie Kafki zostaje skonfrontowane z rosłą posturą ojca bohatera. Następnie przy talerzu głowy rodu dostrzec można niewielkiego rozmiarów owada. We wcześniejszym fragmencie insekt, w którego przemieniał się bohater, odzwierciedlał jego emocjonalny stosunek do samego siebie. Scena rozgrywająca się przy rodzinnym stole w równym stopniu odnosi się do stanu duchowego Kafki, a przede wszystkim metaforycznie ujmuje trudne i złożone relacje łączące pisarza $\mathrm{z}$ własnym ojcem. W przypadku filmowego bohatera $\mathrm{z}$ łatwością daje się dostrzec, że postać głowy rodu pod względem psychicznym i fizycznym ma w sobie coś obezwładniającego. Kafka, pragnąc opisać despotyczny charakter ojca, postanowił w swoim słynnym Liście do ojca zobrazować m.in. sposób zachowania Hermanna Kafki przy stole ${ }^{37}$. W utworze tym zresztą pisarz porównuje się do robaka i pasożyta, co pokazuje, jak przytłaczający był dla niego ciężar autorytetu ojca ${ }^{38}$. Jak twierdzi Kafka „wobec Ciebie [Hermanna Kafki - dop. K.K.] utraciłem wiarę $\mathrm{w}$ swe siły, zamieniłem ją na bezgraniczne poczucie winy"39. W kontekście chorobliwej relacji pomiędzy pisarzem a jego ojcem niezwykle istotna okazuje się scena, w której bohater wyobraża sobie postać kobiety i dziecka siedzących z nim przy wspólnym stole. Kafka wielo-

${ }^{36}$ B. Kosecka, dz. cyt., s. 134.

37 F. Kafka, Cztery opowiadania. List do ojca, przeł. J. Kydryński i J. Ziółkowski, Warszawa 2003, s. 192-193.

38 Tamże, s. 224-225 i 244-246.

39 Tamże, s. 217. Kafka w dalszej części Listu do ojca pisze: „Nieufność wobec większości ludzi, jakiej usiłowałeś nauczyć mnie w sklepie i w rodzinie (wymień mi jednego w jakiś sposób ważnego dla mnie w dzieciństwie człowieka, którego choć raz doszczętnie nie skrytykowałeś), [...] - ta nieufność, której prawdziwości ja, malec, nigdzie naocznie nie potwierdziłem, wszędzie bowiem widziałem tylko niedościgle doskonałych ludzi, stała się we mnie nieufnością do samego siebie oraz ustawicznym strachem przed wszystkimi innymi". Tamże, s. 217-218. 
krotnie w gorzkim tonie wyrażał się o swoim kawalerskim stanie i w słowach pełnych tęsknoty mówił o pragnieniu założenia własnej rodziny ${ }^{40}$. W Liście do ojca pisał:

małżeństwo jest niewątpliwie rękojmią najbardziej radykalnego wyzwolenia się i niezależności. Miałbym rodzinę, wartość najwyższą, jaką w moim mniemaniu można osiągnąć, a więc również wartość najwyższą, jaką Ty osiągnąłeś - dorównywałbym Tobie $[\ldots]^{41}$.

Jak wskazuje przytoczony fragment, Kafka w założeniu własnej rodziny upatruje szansę, aby pod względem emocjonalnym i psychicznym wyswobodzić się spod wpływu własnego ojca. Tym bardziej intrygujące okazuje się, w jaki sposób Dumała odnosi się do przytoczonej sceny:

Kafka, zapytany zdaje się przez lekarza, czy jest kawalerem, wyobraził sobie taką możliwość, że na dwóch pozostałych krzesłach siedzi jego żona i dziecko. I odczuł niesamowitą odległość tej możliwości. Kafkę fascynowało przymierzanie się do czegoś nieosiągalnego ${ }^{42}$.

Zestawienie ze sobą obu wypowiedzi pozwala zauważyć, że to, co pisarz określa mianem wyzwolenia i niezależności, reżyser opisuje jako nieosiągalne. Uwaga ta jest szczególnie interesująca ze względu na wcześniejsze rozważania dotyczące motywu drzwi w twórczości Kafki. Łukasz Musiał przywołuje w swojej książce rozważania Reinera Stacha, który w biografii poświęconej praskiemu autorowi pisze, że:

Kafka [...] nieustannie poszukiwał obrazu, który złączyłby w sobie bliskość i dal, nieskończoną dal tego, co najbliższe, oraz prowokującą bliskość niedosięgłej, mimo to «prawie» osiągalnej dali. I znalazł taki obraz, to - drzwi ${ }^{43}$.

Uwagę Reinera Stacha doskonale odzwierciedla opowiedziana w Procesie legenda Przed prawem, w której „człowiek ze wsi” jest bliski, a zarazem daleki odkrycia tajemnicy kryjącej się za tytułową „bramą prawa”. Wyzwolenie pozostaje dla bohaterów Kafki na wyciągnięcie ręki, chociaż w ostatecznym rezultacie okazuje się nieosiągalne. W identyczny sposób pisarz komentował zresztą perspektywę ewentualnego małżeństwa. $\mathrm{Z}$ jednej strony Kafka dostrzega w ożenku możliwość własnego „wyzwolenia” i „niezależności”, a z drugiej strony zarzuca sobie zbytnią naiwność w tej kwestii:

40 Zob. F. Kafka, Cztery opowiadania..., s. 239-240; tenże, Dzienniki 1910-1923 (część pierwsza), przeł. J. Werter, Londyn 1993 s. 160-161, 174; tenże, Dzienniki 1910-1923 (część druga)..., s. 226 i 229.

${ }^{41}$ Zob. tenże, Cztery opowiadania..., s. 239.

${ }^{42}$ T. Sobolewski, P. Dumała, dz. cyt., s. 14.

${ }^{43}$ Ł. Musiał, dz. cyt., s. 270. 
Rzeczywiście byłoby jak w bajce, ale [...] skoro w tej nadzwyczaj nieszczęsnej relacji, w jakiej pozostaję z Tobą, chcę się usamodzielnić, muszę uczynić coś, co możliwie nie ma żadnego związku z Tobą; ożenienie się jest wprawdzie rzeczą najznamienitszą i daje najbardziej chlubną niezależność, lecz jednocześnie pozostaje także w najściślejszym związku z Tobą. [...] Wobec tego [...] drzwi do małżeństwa są dla mnie zamknięte [podkr. - K.K.], bo jest ono właśnie Twą najbardziej swoistą domeną ${ }^{44}$.

W odczuciu Kafki założenie własnej rodziny tylko iluzorycznie stanowiłoby wyraz jego wolności i niezależności. Spoglądając na inne fragmenty Listu do ojca, trudno uwolnić się od przeświadczenia, że decyzja o małżeństwie nie byłaby urzeczywistnieniem pragnień samego pisarza, lecz spełnieniem pewnych pokładanych w nim oczekiwań, a tym samym podporządkowaniem się woli znienawidzonego ojca. Nie sposób mówić o wolności w sytuacji, w której postanowienie o założeniu rodziny odzwierciedlałoby próbę przyjęcia pewnej z góry narzuconej roli.

Filmowy bohater, podobnie jak sam Kafka, wydaje się pełen sprzeczności. Jest w pełni świadomy, do jakiego stopnia życiowe wybory i wolność człowieka są determinowane przez najróżniejsze czynniki. Kafka nieustępliwie szuka płaszczyzny, która uchroniłaby go przed poczuciem zniewolenia. Przeważająca liczba scen rozgrywających się w zamkniętej, wręcz klaustrofobicznej, przestrzeni potęguje wrażenie, że na bohaterze ciąży pewne jarzmo. Żyjące w akwarium rybki obserwowane przez Kafkę są poetyckim obrazem doskonale współgrającym z charakterem filmowej scenerii. Nieprzypadkowo zresztą po opisanym ujęciu następuje rozdział zatytułowany 11 września, sen, w którym pokazuje się m.in. mapę przedstawiającą morze oraz wizerunek ulicy $\mathrm{z}$ widocznymi w tle drapaczami chmur. Jak zauważa Barbara Kosecka:

W Dziennikach [Kafki - dop. K.K.] pod datą 11 września 1912 roku rzeczywiście pojawia się akapit zatytułowany: Sen, rozpoczynający się od słów: Znajdowałem się na wbudowanym daleko $w$ morze cyplu $z$ ciosowych kamieni... i w ciągu dalszym opisujący wrażenia z pobytu nad jakimś nieznanym morzem, także widok portu w Nowym Jorku ${ }^{45}$.

Jak sugeruje nazwa rozdziału, bohater Dumały poszukuje właśnie w świecie wyobraźni pewnej formy wyzwolenia. Zresztą Kafka wyraźnie zaznaczał w Liście do ojca, że w „ucieczce [...] wewnętrznej” upatruje on

${ }^{44}$ F. Kafka, Cztery opowiadania..., s. 239-240. ,jestem duchowo niezdolny do ożenku. [...] Właściwie powodują to nie troski [...] lecz [...] ogólne brzemię strachu, słabości, pogardy dla samego siebie”. Tamże, s. 239.

${ }^{45}$ B. Kosecka, dz. cyt., s. 133. 
możliwość, aby uchronić się przed ciągłymi groźbami i niezadowoleniem ojca46. Pisarstwo stanowiło dla Kafki formę azylu w świecie wyobraźni. Było ono nawet przez praskiego literata traktowane jako ocalenie się od śmierci ${ }^{47}$. W jednej ze scen, rozgrywającej się w nocnej scenerii, główny bohater siedzi i przy świetle świecy zapisuje kolejne kartki. W wyniku wtargnięcia do pokoju ojca Kafki tworzy się przeciąg. Ten nagły podmuch wiatru prowadzi do symbolicznego zgaszenia świecy. Domniemana postać ojca sprawia wrażenie pewnej zewnętrznej brutalnej siły, która nieoczekiwanie ingeruje w wewnętrzne życie pisarza. Scena ta doskonale zresztą koresponduje $\mathrm{z}$ fragmentem Listu do ojca:

Lepiej utrafiłeś swoją niechęcią w moje pisanie [...]. Tu faktycznie samodzielnie oddaliłem się trochę od Ciebie [Hermanna Kafki - dop. K.K.], nawet jeśli przypominało to nieco robaka, który przydepnięty z tyłu stopą, odrywa się przednią częścią i wlecze na bok. Byłem poniekąd bezpieczny, to była chwila oddechu; odraza, którą oczywiście natychmiast miałeś również do mego pisania, była tu - wyjątkowo - chętnie przeze mnie widziana. Moja próżność, moja ambicja cierpiały wprawdzie z powodu Twego, powszechnie nam znanego powitania mych książek: „Połóż to na nocnym stoliku!” [...], lecz w gruncie rzeczy czułem się jednak przy tym dobrze, nie tylko z powodu podnoszącej się w proteście złośliwości, nie tylko z powodu radości $\mathrm{z}$ nowego potwierdzenia mego poglądu na nasze stosunki, lecz całkiem naturalnie, ponieważ ów utarty zwrot brzmiał dla mnie mniej więcej jak: „Teraz jesteś wolny!” Oczywiście było to złudzenie, nie byłem, bądź w najlepszym wypadku jeszcze nie byłem wolny ${ }^{48}$.

Pisarstwo staje się dla Kafki pewną wyprawą w świat wyobraźni, która zderza się jednak ze zwykłą codziennością, przez co przynosi bohaterowi po raz kolejny tylko chwilowe ukojenie.

Spoglądając na powyższe rozważania, nietrudno zrozumieć, dlaczego Tadeusz Sobolewski w wywiadzie przeprowadzonym z Piotrem Dumałą zauważył, że „Kafka nie jest wolny. Wolności nie ma. On wie, że nie da się przezwyciężyć zasadniczej przeszkody. Stoi przed zamkniętymi drzwiami, które się nie otworzą"49. Zgodnie z wymową filmu, poszukiwane przez bohatera wyzwolenie jest nieosiągalne. Los tytułowej postaci, jak pokazuje Dumała, jest z góry przypieczętowany, a jej starania od początku skazane na niepowodzenie. Konkluzja ta wypada jeszcze bardziej ponuro, jeżeli weźmie się pod uwagę słowa samego Dumały: „dla mnie

${ }^{46}$ F. Kafka, Cztery opowiadania..., s. 199 i 213.

47 Zob. T. Mackiewicz, Autobiografizm Kafki. Semantyka i pragmatyka, [w:] Twórczość Franza Kafki. Tożsamość kulturowa literacka, pod. red. D. Kalinowskiego, Słupsk 2005, s. 72; M. Blanchot, Wokót Kafki, przeł. K. Kocjan, Warszawa 1996, s. 120.

${ }^{48}$ F. Kafka, Cztery opowiadania..., s. 224.

49 T. Sobolewski, P. Dumała, dz. cyt., s. 15. 
Kafka jest kimś, poprzez kogo patrzę na człowieka. [...] «Byłże to ktoś jeden? Czy byli to wszyscy?» - te zdania z Procesu miały być mottem tego filmu?"50.

\section{LITERATURA}

Blanchot M., Wokót Kafki, przeł. Krzysztof Kocjan, Warszawa 1996.

Dumała P., Franz Kafka - scenariusz, „Kwartalnik Filmowy” 1999, nr 26-27, s. 324-325.

Dumała P., „Kafka”, którego nie było, „Kwartalnik Filmowy” 1999, nr 26-27, s. 322-323.

Dumała P., Drygas M., Gazda J., Dochodzenie do Dostojewskiego, „Kwartalnik Filmowy" 1997, nr 19-20, s. 102-123.

Giżycki M., Wyobraźnia zaklęta w kamieniu, „Kwartalnik Filmowy” 1997, nr 19-20, s. $124-125$.

Grözinger K.E., Kafka a Kabała. Pierwiastek żydowski $w$ dziele i myśleniu Franza Kafki, przeł. J. Güntner, Kraków 2006.

Jonas H., Gnostycyzm a umystowość klasyczna, przeł. M. Klimowicz, „Znak” 1991, $\mathrm{nr}$ 7, s. 11-24.

Kafka F., Cztery opowiadania. List do ojca, przeł. J. Kydryński i J. Ziółkowski, Warszawa 2003.

Kafka F., Dzienniki 1910-1923 (część pierwsza), przeł. J. Werter, Londyn 1993.

Kafka F., Dzienniki 1910-1923 (część druga), przeł. J. Werter, Londyn 1993.

Kafka F., Listy do Mileny, przeł. F. Konopka, Kraków 1993.

Kafka F., Listy do rodziny, przyjaciót, wydawców, wybrał, przeł. i komentarzem opatrzył R. Urbański, Warszawa 2012.

Kafka F., Sprawozdanie dla Akademii [w:] Wyrok, przeł. J. Kydryński, Warszawa 1993, s. 104-115.

Kosecka B., „Franza Kafka” Piotra Dumaty - Realizm animacji, „Kwartalnik Filmowy" 1997, nr 19-20, s. 130-138.

Musiał Ł., Kafka. W poszukiwaniu utraconej rzeczywistości, Wrocław 2011.

Musiał Ł., W poszukiwaniu straconego Kafki, „Teksty Drugie” 2013, nr 6, s. 221-241.

Pawel E., Franz Kafka. Koszmar rozumu, Warszawa 2003.

Polski film animowany, pod red. M. Giżyckiego i B. Zmudzińskiego, Warszawa 2008.

Sobolewski T., Dumała P., Kafka jako bohater filmowy. Spotkanie z Piotrem Dumała, „Kino” 1992, nr 6, s. 13-17.

Sokel W.H., Franz Kafka, New York, London 1966.

Tarkowski A., Młoda polska animacja jeszcze raz: Dumała, Rybczyński, Wawszczyk, <http://kultura20.blog.polityka.pl/2008/03/18/mloda-polska-animacja-jeszcze-razdumala-rybczynski-wawszczyk/>, dostęp: 08.10.2015.

Twórczość Franza Kafki. Tożsamość kulturowa literacka, pod. red. D. Kalinowskiego, Słupsk 2005.

50 Tamże, s. 15. Zob. też. P. Dumała, Franz Kafka-scenariusz..., s. 324. 
